Open Access

\title{
Political activities and anti-communism of Korean Protestant conservatives in the 2000s
}

Dae Young Ryu

Correspondence: ryudy@handong.edu

Handong University, Pohang, South Korea

\begin{abstract}
Korean Protestant Conservatives began political activities against the government when the Roh Moo Hyun administration took office. Conservative Protestants have long been obedient to the government and kept silence on socio-political issues since the foundation of the Republic of Korea. Those politically active conservative Protestants were called the Christian Right. Their sudden political activism came from a sense of crisis they felt about the Kim Dae Jung and Roh Moo Ryun governments' progressive policies. It arose in a "power vacuum" that even though the progressive governments took political power, the "Cold War structures" still dominated many sections of Korean society. The Christian Right, just like the ideological right, was formed due to a sense of ideological crisis. It thought that the Kim and Roh administrations were pushing Korea, the rightist republic as it believed, into a crisis by adapting leftist policy measures. Their key values were pro-Americanism and anti-communism. Just like American Religious Right, their anti-communism was connected to Manichaean dualism, fundamentalism, and a belief in the providential role of the United States in fight against evil. However, unlike the American counterpart, the Korean Christian Right paid little attention to ethical issues, while making issue of ideological and socio-political matters only.
\end{abstract}




\begin{abstract}
Abstrakt
Die koreanischen konservativen Protestanten fingen an, ihre regierungsfeindliche politische Haltung gegen die Regierung von Roh Moo Hyun einzunehmen. Seit der Staatsgründung haben die konservativen Protestanten stets eine friedliche Haltung gegenüber der Regierung eingenommen und verhielten sich zu den soziopolitischen Problemen eher zurückhaltend. Aber plötzlich zeigten die sogenannten "christlichen Konservativen" ihre regierungsfeindliche Haltung gegenüber der Roh Regierung; denn sie beurteilten die fortschrittliche Politik der Regierung von Kim Dae Jung und Roh Moo Hyun als eine Gefahr. Als die "Linken“ die Macht übernommen hatten, war die koreanische Gesellschaft immer noch im "System des Kalten Krieges” gefangen und ein "Machtvakuum" war dadurch entstanden. Die rechtsradikalen Christen sind wie auch alle andere ideologische Rechtsradikalen - durch die ideologische Krise entstanden. Sie waren der Meinung, dass die Kim Dae Jung und Roh Moo Hyuns Regierung durch ihre "Pro-Nord Korea" und "Linken" Politik die koreanische Republik in die Krise stürzte. Ihre wesentlichen Werte waren Proamerikanismus und Antikommunismus. Ähnlich wie bei amerikanischen religiösen Konservativen hatte ihre antikommunistische Haltung eine Verbindung zum manichäischen Dualismus, Fundamentalismus und zu dem Glauben in der zugedachten Rolle der Vereinigten Staaten im Kampf gegen das Böse. Jedoch zeigten die koreanischen christlichen Konservativen - im Gegensatz zu amerikanischen christlichen Konservativen - nur ihr ideologisches bzw. politisch-wirtschaftliches Interesse, ohne auf die ethische Problematik einzugehen.
\end{abstract}

Keywords: Korean Convervative Protestants, Anti-Communism, Pro-Americanism, The Korean Christian Right, The American Religious Right, Fundamentalism, Manichaeism, Common-Sense Realism

\title{
Introduction
}

On the March First Independence Movement Day in 2004, a mass meeting was convened in the Seoul City Hall Square. It was "The Independence Movement Day National Meeting to Eradicate the Pro-North Korea Leftists and Corruption" organized by "The National Council for Anti-Nuclear, Anti-Kim Jong-Il National Sovereignty Protection." ${ }^{1}$ People who participated in this "national meeting" were apparently ideological conservatives. Participants declared in a resolution that "free democracy is being shaken by irresponsible pro-North Korea leftists," and urged the so-called "pro-North Korea, anti-America leftists" to stop threatening the nation's foundation and security in the "guise of democratization and reforms." 2 To the protesters, those who had a forward-looking attitude toward North Korea were the "pro-North Korea leftists" who needed to be eliminated. Interestingly, Protestant Christians led the gathering. Ministers from the Christian Council of Korea (CCK) took part in the mass meeting in droves, and many of the participants were Protestants whom they had urged to attend. In other words, the CCK, which has represented Korea's conservative Protestant churches since its establishment in 1989, began to take an important role in a political "counterattack" by the conservative camp. ${ }^{3}$

It was around the end of the Kim Dae-Jung administration that Korea's conservative camp suddenly gathered together to act publicly against the government. Yet the conservative camp's "counterattack" did not become serious until the Roh Moo-Hyun administration took office. Over the course of a few months from late 2004, that is, about 
two years after the Roh administration was inaugurated, to early 2005, some 30 rightwing civil groups sprang up. This resulted from a cohesion of the right wing that started during the Kim administration and was strengthened as the Roh government came in. Unlike previous civic groups, the newly formed groups all made an issue of the government's "left-wing" ideology. They claimed that the "pro-North Korean leftist" Roh administration was violating the legitimacy and the constitution of Korea, and undermining its free-market economy. Conservative media agencies such as The DongA Ilbo and The Chosun Ilbo began reporting on the sudden rise of these right-wing civic groups. In early November of 2004, The Dong-A Ilbo called the groups the "Korean 'New Right" in a feature article. ${ }^{4}$ From that moment, the right-wing civil groups were commonly called the New Right. The New Right became increasingly active over time. A number of new groups were formed, while the existing groups expanded their organization by joining forces. In its September 2005 issue, Monthly Chosun reported that "the Renaissance of the Right," spearheaded by the emergence of the New Right, paved "the ground for the revival of conservatism."

At first, Korea's New Right movement was led by intellectuals, professionals, and pundits. Then, after late 2005 when the theory and political alternatives of the movement had largely been established, the movement was expanded as a popular campaign. Conservative Protestants joined the New Right to become leaders of its popularization. Conservatives had either conformed to or cooperated with previous authoritarian regimes, appealing to the principle of the separation of church and state. Protestants who joined the New Right movement, however, abandoned the old political conformism and started to act against those in power. What then made the CCK, a religious group, work with far-right ideological conservatives such as the Korean Veterans Association and various other war veterans' groups? This paper tries to explain why Protestant conservatives participated in the ideological "counterattack" by the political far right in the 2000s and examines some unique features of their worldview. In that regard, it investigates the historical background of Protestant anti-communism, reasons that led Protestant anti-communists to act, and characteristics of their anti-communism.

\section{History of anti-communism among Korean Protestants}

The dictionary defines "conservatism" as cherishing something old, and keeping and maintaining it as it is. In that sense, "conservatism" is the concept that most contradicts "change." Conservatives are generally repulsed by change. They believe that not all change is progress and the test for anything is not whether it is progressive, but whether it is right. ${ }^{6}$ If conservatism is defined as an attitude of keeping something intact without making a change, or repulsion toward change, social and political conservatism can be understood as resistance to social and political change. The Kim Dae-Jung administration, which took office in 1998, was the first government since independence formed by an opposition party after winning a presidential election. It was in line with the Roh Moo-Hyun administration that followed it. The two governments pursued policies that were distinctively different from the previous anticommunist, right-wing governments, thereby bringing about a number of "changes" both in society and people's minds. Some of the most representative changes included democratization, diversification, and the dismantling of Cold War structures. A 
forward-looking attitude toward North Korea, shifts toward inter-Korean reconciliation and reunification, recognition of diverse values, and a general reorientation toward a non-authoritarian and equal society took place. Therefore, rejection of such progressive socio-political changes can be viewed as social and political conservatism.

Social and political conservatives strove to keep what they were trying to conserve by mounting a counterattack to changes made during the Kim and Roh administrations. ${ }^{7}$ It seems that some of the biggest changes that forced them to act were the weakening of anti-communism in Korean society due to the progress of the post-Cold War era and the spread of animosity toward the United States. These social changes threatened conservatives' essential values of anti-communism and pro-Americanism, and shook their fundamental worldview. Therefore, they felt compelled to respond aggressively to those changes. Considering that they had clung to anti-communism and proAmericanism, conservatives understandably had to respond to the post-Cold War changes by making efforts to protect anti-communism and pro-Americanism.

This paper places its focus on the link between theological conservatism and sociopolitical conservatism. The aforementioned "national meeting" held in the Seoul City Hall Square seems to indicate that there is a rational and practical common ground between these two. More than anything else, what connected the two forces seems to have been an ideological consensus on anti-communism. U.S. history tells us that American Protestant conservatism has held an anti-communist attitude since its beginning in the 1920 - 30s. Among American Protestant conservatives, however, those who became the ideological far right and actively campaigned for anti-communism were mostly fundamentalists. ${ }^{8}$ In Korea, too, there seemed to be a close relationship between the "counterattack" by the Protestant rightists in the 2000s and theological fundamentalism.

Historically, Korean Protestants' anti-communism arose when it first collided with the Marxism introduced to Korea in the 1920s. Protestants had to respond in some way to the challenge from the Marxist-socialists who were promoting an anti-Christian campaign as part of their anti-religious propaganda. A few Protestants who encountered Marxism became quite interested in the common people and even accepted socialism. Yet most Korean Protestants were vehemently hostile toward Marxism. It appears that two factors were at play here. One was western missionaries' antipathy to Marxism. Missionaries of the time were mostly from the Anglo-American middle classes and upheld the values of the capitalist market economy as the North American and European middle classes did. Moreover, having grown up in the mainstream middleclass churches, they shared the deeply rooted antipathy of the British and America mainstream Protestants to atheism and materialism. When the missionaries were still dominating Korea's Protestant scene, their anti-communist sentiment must have had a significant impact on Korean Protestants' theology and their outlook on the world.

The other factor was Imperial Japan's policy that brutally suppressed Marxism as a threat to its regime and instilled anti-communism in the people. ${ }^{9}$ In the wake of the First World War, Japan became the world's third-largest military and economic power and turned into a strong capitalist nation that pursued imperialistic expansion by competing with Western powers. In particular, as it began invading Manchuria and other regions of the Asian Continent in the 1930s, Japan became a Fascist nation governed by extreme right-wing nationalists. Furthermore, since the mid-1920s, 
Japanese colonial rulers saw popular-nationalist movements inspired by Marxism frequently arise in Korea. ${ }^{10}$ Marxist activists led countless peasant movements such as in the Amtae Island Tenancy Dispute (1923-24) and workers' disputes like the Wonsan General Strike (1929). In response, Japan adopted tough anti-communist policy measures in Korea and urged each church to cooperate.

In some ways, Japanese colonial rulers and missionaries were in conflict, but they were also in a symbiotic relationship. Anti-communism was a common ground that was in the interests of both parties. A case in point is the relationship of American Presbyterian missionary George S. McCune and Governor-General Saito Makoto. ${ }^{11}$ McCune came to Korea in 1905, but had to give up his missionary work and return to the United States because of his son's illness. However, he came back to Korea as a missionary in 1920. He did so because he was invited by Saito. After returning to the States, McCune became the president of Huron College in South Dakota and actively promoted an anti-communist campaign there. Saito heard of it and invited McCune back to Korea believing that his experience and influence would be useful in the fight against Marxist movements that were popular among nationalistic Koreans at the time. McCune actively worked with policies of the Japanese Government-General of Korea on anti-communism education while running the Boys Academy in Seoncheon, and Soongsil Academy and Soongsil College in Pyongyang. Other missionaries were not different from McCune and disliked Marxism. Their writings were replete with worries about and polemics against Marxism and other radical ideas. ${ }^{12}$

Anti-communism, to which the vast majority of Korean Protestants held fast throughout the period of Japanese occupation, was greatly intensified as Christians personally encountered Marxism after liberation and through the Korean War. Due to Japan's anti-communist policy, ordinary Korean Christians rarely had a chance to deal with the leftists under Japanese colonial rule. Then, immediately after liberation, Christians in the North collided with Marxists who were seizing the northern parts of the Korean peninsula. Churches in the northern areas were predominantly composed of capitalist middle-class, land-owning adherents, who used to conform to Japanese colonialism. Hence, a conflict with communist North Korean authorities was inevitable. The Presbyterian churches of Pyongyang and northwestern regions had a fundamentalist theology acquired from fundamentalist Presbyterian missionaries and were hostile to Marxism. They were the mainstay of Korean Protestantism at that time. Some progressive Protestant Christians embraced the establishment of a socialist regime. However, the Marxist ideology threatened the socio-economic status of many Christians, forcing them to carry out the "Exodus" to the capitalist South controlled by the U.S. military government. The escape was motivated as much by ideological and socio-political reasons as religious. ${ }^{13}$ However, Han Kyung-Jik and other Protestant leaders who fled from North Korea justified their escape by making anti-communism a theological cause. They declared that North Korea's Marxist-socialist regime was an apocalyptic anti-Christ. $^{14}$

Meanwhile, South Korea saw an intense ideological conflict between the left and the right. A vast majority of Protestants supported the establishment of a separate and independent government in South Korea led by Rhee Syngman and supported by the United States. Rhee and South Korean Protestants were ideologically of one mind. Some Protestant leaders including Kim Gu, Kim Gyu-Sik, and Kim Jae-Jun argued for a 
unified government only to be either murdered or accused of being pro-communist by the conservative right. Some Christian socialists such as Kim Chang-Jun chose the North and moved there. Ultimately, as the liberated nation went through political division, the church, too, split along ideological lines. Protestant defectors from the North became leaders of South Korean churches. ${ }^{15}$ Their staunch anti-communist and proAmerican convictions made Protestantism a leading force of anti-communism and proAmericanism in South Korea. They treated the North Korean regime with hostility and did not recognize pro-communist Christians in North Korea as Christian, believing that the North Korean regime had eradicated Christianity.

While cooperating with the U.S. military government and Rhee Syngman, South Korean Protestants enjoyed various benefits and preferential treatment. ${ }^{16}$ Church leaders, under the influence of American missionaries and their experience of studying in the United States, were pro-American. They regarded the United States as a model for the new Korean republic after independence from Japanese rule. Both the conservative Han Kyung-Jik, who came to the South fleeing the socialist regime, and the liberal Kim Jae-Jun, who dreamt of a unified government that would embrace socialism, were pro-American. Rhee Syngman, the first President of the Republic of Korea, wanted to make it "the first Christian nation in Asia." ${ }^{17}$ His government, sustained by the support from rightists and the United States, remained strongly anti-communist and proAmerican. Some church leaders made a connection between anti-communism and apocalyptic theology. They stood in the forefront of anti-communism and the fight to defeat communism. Arguing for a "northward reunification" even before the Korean War, they opposed a ceasefire throughout the Korean War. ${ }^{18}$

The bloody Korean War left South Koreans and North Koreans with an insurmountable hatred of communism and the United States (and Christianity), respectively. The division became permanent not just politically and ideologically, but also emotionally. That was well demonstrated by Kim Jae-Jun who said after the war that a sympathetic feeling toward communism was "delusional." ${ }^{19}$ After the Korean War, Christians in South Korea all became staunch anti-communists regardless of their theological stance. The United States led the Korean War on the one hand while providing a massive relief efforts through churches on the other. ${ }^{20}$ Consequently, it further strengthened proAmericanism among Korean Protestants, and anti-communism and pro-Americanism came to be indivisible.

Due to the armistice, South Korea's anti-communist Protestant leaders lost an opportunity for achieving reunification by force. When the war ended, they began attacking and disrupting various attempts for a peaceful reunification, inter-Korean exchanges, and reconciliation by stressing that they could not coexist with communism. As far as anti-communism was concerned, the National Council of Churches in Korea (NCCK) was no exception, even though the umbrella organ of relatively liberal denominations led the democratization movement during the period of military dictatorship. For instance, based on anti-communist spirit, the NCCK strongly supported the Korean government's decision to dispatch military forces to fight against the Vietnamese communist-nationalists in the Vietnam War. ${ }^{21}$ Afterward, the NCCK interrupted North Korean Christians' efforts to make exchanges with the World Council of Churches and Korean Christians overseas. ${ }^{22}$ These cases indicate that anti-communism took deep root among South Korean Protestants regardless of 
their theological differences. Leading Protestant activists against Park Jung-Hee's dictatorship, including Kim Jae-Jun, Mun Ik-Hwan, and Jang Jun-Ha, were basically anti-communists, as well. Minjung Theology, the Korean version of the progressive praxis theology that strongly encouraged Christian social engagement, distanced itself from Marxism. ${ }^{23}$

A forward-looking attitude toward North Korea first appeared among South Korean Protestants in the aftermath of the Gwangju Democratization Movement in 1980. The movement opened a crack in South Korean Protestants' uniform anti-communism. Awareness that some of the most significant socio-political issues in Korea fundamentally arose out of the national division increased among progressive Protestants. Naturally, opposition to the United States, a major power that created and maintained the divided system, began to surface. A protest for democratization was converted into a protest for reunification, which inevitably generated a conflict with anti-communism and pro-Americanism. Conservative Protestant churches, which remained silent throughout the military dictatorship, did not take part in a reassessment of the United States and a shift toward post-Cold War society that was gaining steam after the Gwangju Democratization Movement. They were still accustomed to the framework of the Cold War and upheld the pro-American and anti-communist values that supported it. From the end of the Korean War until the 2000s, they rarely took to the streets voluntarily for political purposes. What, then, made some members of conservative churches gather in front of the city hall, wave the Stars and Stripes, and express their hostility toward the so-called pro-North Korean leftists by singing "Up and Fight against the Devil"?

\section{"Power vacuum" and the political activism of conservative Protestants}

Conservative Protestants' political activism materializes when certain external factors coincide with one another. For starters, there needs to be a situation that seriously threatens the conservatives' worldview. A case in point is conservative Protestant churches in the United States. They grew by adapting to capitalist pecking orders, and the adherents were obedient to authorities. This disposition, combined with conservative Protestantism's unique theological tendency to reduce all matters to personal issues, led to indifference to or silence on socio-political issues. Yet, as they witnessed their society gradually proceeding in a way they did not want, they came to realize the disoriented society could shake the foundation of their values. That is when conservatives became determined to "change" society. ${ }^{24}$ For their part, it was not the ones who were protecting what is right who should change but the world that was moving in a "wrong" direction. ${ }^{25}$

However, conservative Protestants who are used to complying with the socioeconomic status quo and the authorities do not try to jump into real politics only because they feel social changes could put their theological worldview at risk. They need charismatic leaders who keep them motivated and incite them to action. It is known that popular leaders of conservative churches tend to feel changes in socio-political power very sensitively. A study found that when American fundamentalist leaders sense a certain "power vacuum," they get interested in filling it. ${ }^{26}$ In the 1970 s, a Christian right-wing movement arose in the United States, and conservative Protestants became 
politically active. That was possible only when the two conditions, that is, a sense of crisis and a power vacuum, met. Supreme Court rulings such as a ban on group prayer in public schools (1961) and the legalization of abortion (1973) gave conservative Protestants a sense of crisis that secular liberalism was shaking the ethical foundations of the United States. In addition, various changes brought by modernity, which most Americans considered the wave of the future, were leading to a sharp increase in divorces, a prevalence of pornography, and a rise in drug and alcohol addiction. Hence, the morality of modernity became undermined, creating a "power vacuum." Right-wing Christian leaders utilized this as an opportunity to bring conservative Protestants together and created political movements.

This also explains why some conservative Korean Protestant churches joined hands with politically extreme rightists and clamored for anti-communism and proAmericanism when Kim Dae-Jung and Roh Moo-Hyun were presidents. Liberal Protestants, who actively participated in democratization protests from the 1970s to the 1980s, had enjoyed a sort of moral monopoly regarding social engagement. Conservative churches, which remained silent during the period of protests, found themselves in an embarrassing position where they could find no theological excuse to justify the silence. Some conservative Protestants began engaging in social activism after the late 1980s both as a result of self-questioning of past behavior and as a reaction to the moral dominance of their progressive brethren. As Korea entered the period of democratization in the wake of the "June Democracy Movement" of 1987, revolutionary struggles dominated by progressives came to an end, and the so-called "period of reformism" by civil movements arrived. Socially active conservative Protestants joined civil movements in the 1990s. ${ }^{27}$ The expansion of reformist civil movements led to a dramatic collapse of liberals' moral superiority; it also helped create two of the most progressive governments since the liberation from Japanese occupation.

The Kim Dae-Jung administration's "Sunshine Policy" toward North Korea reflected the post-Cold War trend around the world. It accompanied an ongoing attempt to reassess the relationship with the United States since the Gwangju Democratization Movement, and jeopardized anti-communism and pro-Americanism, the foundation of Korean conservatives' worldview. This development enraged the far rightists, and some of them began to take one reactionary action after another. Nevertheless, Protestant conservatives kept silent for the moment. Then, contrary to the wishes of conservatives, the Kim administration was succeeded by the Roh administration. Seeing a reform-oriented president again in the Blue House, they finally launched a counterattack and generated great political turmoil, including an attempt to impeach President Roh Moo-Hyun in 2004.

It seems that this situation finally presented conservative Protestants, who had been looking for an opportunity to move, with a "power vacuum." The so-called reformists who had taken power since the Kim administration failed to solidify shifts toward a post-Cold War society, democratization, and diversification. On top of that, several corruption scandals involving key figures from the two administrations broke out. Although not comparable to crimes committed by the previous authoritarian regimes, they seriously undermined the administrations' morality by contradicting their own pledges and the heightened expectations of the public. A reform-oriented party took power, but conservatives were still wielding their power under the formidable 
"Cold War structure" of Korean politics, bureaucracy, media, and business. ${ }^{28}$ Such a situation brought about a "power vacuum" where neither camp was strong enough to hold dominant power.

\section{Anti-communism of conservative Protestants: nationism}

Korea's conservative Protestants felt a sense of crisis, that the emergence of the "leftwing" Kim and Roh governments put their nation at risk, while they sensed a "power vacuum" in Korean society. This situation encouraged them to start a political movement. Their political activities were focused on actual or proposed threats to the foundational principles of the Republic of Korea. The central value that conservative Protestants tried to safeguard was Korea itself, the Korea that they believed to be an anti-communist right-wing republic. Therefore, anti-communism and other relevant values being undermined meant the national identity was in danger. In such a state of crisis, Korea's New Right groups were organized.

In November 2004, when New Right mass organizations had not yet been created, the Christian Social Responsibility was formed to protect Korea out of an awareness that Korea was in "the most difficult situation ever." ${ }^{29}$ About a year later, the Korea Christian Reform Movement joined Solidarity for Liberalism, the Textbook Forum, and other rightist groups to establish the New Right Network, deploring the situation whereby Korea "had lost its way and was thrown into confusion." 30 The New Right National Alliance was similar to them in that it assessed the situation of Korea in a very pessimistic tone. Its statement of establishment released in September 2005 deplored that Korea was in an "overall crisis" and was undergoing a "conflict and confusion more serious than that witnessed during the political situation immediately after liberation."31 The Christian New Right Alliance, an affiliate of the New Right National Alliance, lamented in its founding declaration of July 2007 that Korean society was trapped in a "total crisis as if it had lost general guidance," implying that Korea was in a perilous situation in all sectors, including politics, economy, education, and culture. ${ }^{32}$ The constitutional values were believed to be in great danger.

Amid gradually mounting counterattacks from the New Right on the "left-wing" values of government and society, Protestant conservatives actively participating in the movement with leadership and organizational power began to be called the "Christian New Right." From the perspective of the New Right, the left-wing government was undermining Korea's basic values in every field. In particular, it was concerned about a collapse of the laissez faire market economy. It blamed the leftist government for destroying Korea's long-standing market economy by pursing anti-market, anti-business, and anti-liberal policies based on its "hatred of wealth." 33 In addition, it claimed that the leftists who did not trust the free market also adopted measures to equalize education, legalize the Korean Teachers' \& Educational Workers' Union, and to promote a labor-friendly environment during the Kim and Roh administrations. ${ }^{34}$ Believing that such left-wing policies were hindering Korea from becoming an advanced country, the Christian New Right strove to eliminate them and introduce market-friendly policy measures.

The Christian New Right thought that the leftists were doing massive harm to Korea's legitimacy and identity. It claimed that the leftists turned Korean history into "a history 
of shame" through a "left-leaning view of history" or a "self-tormenting view of history." ${ }^{\prime 35}$ In order to recover the real Korea distorted by the leftist history, the Christian New Right rewrote Korean history according to its own historical perspective and worldview. To the Christian New Right, Korea was a right-wing republic established by the right-wing founding fathers and developed by people promoting modernization, and had a "history of success" until the leftist Kim and Roh administrations. Set up by Rhee Syngman's "realist choice" for a separate government in the South and through a "process of democratic election," the Republic of Korea was a nation without "any flaw in legitimacy." The Christian New Right believed that the national division and the Korean War were entirely attributable to the Soviet Union and Kim Il-Sung. The victims of "friendly fire" by Korean and American soldiers in action during the Korean War were not comparable with the massacre of civilians by the North Korean People's Army. It also insisted that a rapid and successful modernization and industrialization under the rule of Park Jung-Hee was possible only "on the condition" of an authoritarian political system. Inequality in wealth, authoritarian politics, and restrictions on and suppression of human rights were "inevitable side effects and usual sacrifices" that any country around the world would experience in the process of industrialization. ${ }^{36}$

The Christian New Right did not stop its efforts even after Lee Myung-Bak won a presidential election with its support and took office in 2008. The Lee administration claimed to advocate "pragmatism" and, therefore, did not wage a head-on war against the leftists as expected. Hence, the Christian New Right argued that the liberals were still conspiring to seize power even after the Lee administration was inaugurated. The Christian Party leader Chun Gwang-Hoon, who failed to win a seat in the 18th general elections held during the Roh administration, announced a party reshuffle and warned that the leftists were trying to "infiltrate every corner of our society and destroy Korea as a whole." ${ }^{37} \mathrm{He}$ declared that he would resume action to "save the country and people." In a similar vein, the Civil Action for Advancement group viewed the "antiKorean forces" that were "in a strong line-up" after the administration change as a source of crisis. ${ }^{38}$ The group representative, Seo Gyung-Seok, listed specific names, such as the Korean Teachers' \& Educational Workers' Union, the Korean Confederation of Trade Unions, the Korean Federation of Student Councils, and the National Farmers League, as "pro-North Korean leftist forces." 39 He argued that hundreds of thousands of leftists were "rocking the Republic of Korea and threatening free democracy."

Interestingly, Korean Protestant conservatives refer to "liberalism" in a very limited sense. What they mean by liberalism is confined to the free-market economy with minimal government intervention and regulation; that is, liberalism to them basically means an economic idea. ${ }^{40}$ Yet there are other values of liberalism in politics, culture, and thought. A pivotal element of liberalism values individual freedom and rights and thereby strives to guarantee individuals an absolute freedom whereby they can make a choice according to their conscience and lifestyle. Liberalism not only cherishes freedom of thought, religion, and art, but also tries to minimize governmental intervention in such social issues as sex, abortion, gambling, drinking, and addictive substances. The Korean New Right refers to free democracy as an element of liberalism that it pursues. However, it apparently does 
not want their free democracy to protect freedom of thought and activity for "antiKoreans" and "leftists." The Korean New Right looks for liberalism in terms of the economy, but in culture and thought, it seems to be surprisingly totalitarian.

\section{Anti-communism of Korean Protestants: dualism and Pro-Americanism}

Conservative Protestants who began to engage in political activity, have a world outlook that is based on a unique dualism. A scholar, who investigated why U.S. Protestant conservatives, historically characterized by political indifference and non-engagement, suddenly became anti-communist fighters during the Cold War era, found that they had a $>$ peculiar way of thinking. Christian anti-communist fighters in the United States, including fundamentalist leader Carl McIntire who led a witch hunt for imagined communists amid a frenzy of McCarthyism in the early 1950s, were strongly influenced by a Manichean good-and-evil dualism. ${ }^{41}$ According to the Manichean view, the universe is where the two equal forces, light (or good) and darkness (or evil), are fighting each other, and history is a string of "conspiracies" created by evil to take over the world. ${ }^{42}$ With this perspective, conservative Protestants viewed history as a long battle between God and Satan, that is, good and evil, and they strongly believed that they were always on the side of good. This is why American conservative Protestants who began to act politically thought that they were "moral" (or good), while the opposition was "political" (or evil). ${ }^{43}$

American conservative Protestants' belief in Manichean dualism was strengthened by a realist epistemology based on Scottish Common-Sense Realism that many AngloAmerican Protestants shared. Common-Sense Realism taught that human cognition was correct and human knowledge was reliable. ${ }^{44}$ In other words, common-sense philosophers saw that all human beings could instinctively be assured of the objective truths and principles of religious faiths without specific evidence. They called such self-evident knowledge "common sense." The philosophy exerted a profound influence on American conservative theologians such as J. Gresham Machen, and became the foundation of fundamentalist-evangelical theology. ${ }^{45}$ Manichean dualism caused a great synergistic effect when it met with Common-Sense Philosophy. When people saw something appear within a framework of two contradictory things (i.e., good and evil), the epistemology of "common sense" allowed them to clearly understand to which side it belonged. The dualistic worldview and the realist epistemology joined conservative Protestants' sense of urgency that they were lagging behind the mainstream of the United States, and instilled in them a peculiar mentality of fundamentalist anticommunist fighters. ${ }^{46}$

One can easily find Manichean dualism in today's American Christian Right. Christian Right theorists in the United States dichotomize the history of the West and see it as a battle between good and evil. For instance, Francis Schaeffer, a fundamentalist theologian and the "official intellectual" of the Christian Right, viewed the history of the West as a process whereby humanism, originating from Greco-Roman thought, had conflicted with the God-centered view led by Christianity. ${ }^{47} \mathrm{He}$ claimed that humanistic elements had degraded the "original" biblical truth of Christianity, which had eventually brought about the Enlightenment, communism, and secular humanism, destroying the ideas and lives of modern people through decadent 
culture and arts. ${ }^{48}$ While the adherents of Protestant conservatism believe in an omnipotent, good, and one-and-only God, they also think that evil is strong enough to challenge God and take over the world. Therefore, their monotheism is confessional, yet their dualism is empirical. Like Manichaeism, the supporters of the Christian Right divide the world into good and evil and discern who belongs where without hesitation. To them, everything on this planet is either good or evil, light or dark, and true or untrue, and there is nothing in between. The God-centered belief, represented by the Bible, Christianity, and the United States, is a good and bright world, while secular humanism, linked to reason, the mundane world, and "un-Americanism," is an evil and dark world. ${ }^{49}$

McIntire, Schaeffer, and other American fundamentalist leaders and theorists had a direct impact on the way fundamentalism took root in Korea's Protestant churches, especially the Presbyterian Church, after the Korean War. From the beginning, the hallmark of Korean Protestantism was theological and ethical conservatism. ${ }^{50}$ Nevertheless, it was not a monolithic phenomenon. For instance, leaders of the Seoul Station of the American Northern Presbyterian Mission, who had a great influence on the South before liberation, were theologically moderate missionaries. Their theological beliefs were different from those of fundamentalist missionaries in Pyongyang to the point that the two camps were in serious conflict regarding mission school policies and Shinto shrine obeisance. ${ }^{51}$ However, the mainstream American Protestant churches lost much of their passion for overseas missions after the Second World War. They now had a better understanding of non-Christian cultures, and conservative theology, which had mass-produced missionaries in the past, no longer dominated the mainstream Protestant churches. As a result, the missionaries who came to Korea after liberation were mostly those who still adhered to conservative theology or came from fundamentalist denominations. After the Korean War, in particular, American fundamentalist leaders, represented by Carl McIntire, sent missionaries and money to Korea to expand their influence. This triggered theological conflicts within the existing churches, the resulting fragmentation enabling fundamentalists to establish new churches.

The fundamentalist missionaries led to the creation of fundamentalist Protestant denominations in Korea. Along with the fundamentalist Protestants from North Korea in mainline denominations, who had fled to the South after the liberation and during the Korean War, they formed a strong fundamentalist element in South Korean Protestantism. This new alliance of Protestant fundamentalists became a dominant force in the South Korean churches, and created a generally fundamentalist tendency among South Korean Protestantism after the Korean War. The dualism of American fundamentalist theology converged with strong anti-communism in Cold War Korea. Unlike American fundamentalist dualism, its unique Korean version was much more ideologically inclined due to the experience of the Korean War and national division, and the concomitant dominance of Cold-War culture in Korean society.

Korean Protestant fundamentalists were under the constant influence of American fundamentalism through people-to-people exchanges and the introduction of theology. The Korean Christian New Right Movement appeared in the same context. It is not difficult to find traces of conceptualized Manichean dualism in the words of the Korean Christian New Right, which was directly affected by American fundamentalism. Yet, 
Korean fundamentalists were more manifestly anti-communistic than their U.S. brethren. The Christian New Right members called themselves "patriotic groups," "advancement-oriented forces," and "patriotic rightists," whereas they accused their opponents of being "anti-Korean," "anti-advancement forces," and "pro-North Korean leftists." The Christian New Right in Korea included people with various political goals, ranging from establishing a "theocratic state" to achieving "middle-line integration." In their views of the world, however, evil was a specific group dubbed the "left wing." These leftists were the source of all political and social evil as well as the main culprit that was pushing Korea into a crisis.

When compared to the Christian Right in the United States, the Korean Christian New Right believes in a dualism whereby evil more clearly takes the form of left-wing ideology. This aspect is well demonstrated by remarks made by pastors and church members who attended a fasting prayer meeting held in a church before the aforementioned "national meeting" took place in the Seoul City Hall Square. A pastor declared, in his sermon, that "Communism is the No. 1 enemy of Christians," and it was "the Satan and Antichrist of the 21st century." Then, an elder brought up a conspiracy theory in a special lecture that Korea was under "the control of the Red Devil" during the 2002 World Cup. The theory explained that on the red T-shirts that Koreans wore to cheer for the national team was the phrase "Be the Reds," and the red "commies," invited at that time, were disturbing the entire country. ${ }^{52}$

When looking closely, one can discover that the concerns of the Korean Christian New Right are mostly concentrated on political and economic issues. Unlike the Christian rightists of the United States, the Christian New Right in Korea rarely expresses its official stance on social or moral issues. Even on corruption and immorality its discussions are always within the scope of politics and the economy. In other words, it rarely touches upon social and ethical topics that its American counterparts are greatly concerned about, such as abortion, homosexuality, euthanasia, stem cell research, and pornography. This is certainly because Korea's Christian New Right was born of ideological crises arising from a Cold-War mentality endemic for decades, and its interest is centered on ideological issues.

One of the most interesting remarks made during the prayer service above was that the United States was playing a leading role in a fight against communism (and Satan). The elder mentioned above insisted that the U.S. outlook was in line with that of Christianity, and, therefore, opposing such a country was "betrayal" and "ingratitude." He added that the division on the Korean peninsula was not a disaster, but a blessing, and God wanted Korea to become a "suitable helper" for the United States, the leader of world history. According to the Book of Genesis, God created a woman as a "suitable helper" to a man. By using the words from Genesis, the elder tried to place the United States in a superior position to Korea, and simultaneously tried to describe the Korea-U.S. partnership as a relationship as close as that of a married couple. Finally, by saying that Satan was most afraid of the Korea-U.S. alliance and hence promoted anti-Americanism, the elder attached an apocalyptic meaning to the Korea-U.S. alliance and anti-American sentiment. At the end of the meeting, a pastor called for a prayer for the United States, the nation God had posted as a "sentry" for anti-communism. ${ }^{53}$ When the service was over, the attendees headed in droves for the city hall square. 
With an upcoming apocalypse, American Protestant conservatives, who fought in the forefront of a battle against communism during the Cold War, believed that communists were constructing a "plot" to rule the United States. They thought that such communism was the anti-Christ that would appear during the apocalypse, and that the United States, a country that God had chosen to save the world, had a responsibility to devote itself to a fight against communism. ${ }^{54}$ Many of the Korean conservative Protestant leaders believed in the similar providential mission of rescuing the world. In the course of the formation of Korean Protestant anti-communism, a sort of providential elitism whereby Korea was destined to be an assistant to the United States was combined with anti-communism, good-and-evil dualism, and America-centered eschatology. ${ }^{55}$ To the Korean Protestant anti-communists, the United Sates is leading a holy war against evil communism, and Korea is an ally. Consequently, according to their dualistic worldview, anti-Americanism is synonymous with a pro-North Korean attitude, and anything that hurts the Korea-U.S. alliance is a consequence of siding with North Korea and goes against the national interests of Korea.

\section{Conclusion}

One of the most important clues that help one understand conservative Protestants' anti-communism is Manichean dualism. The dualistic world outlook makes one view the world in an extremely simplified way. According to it, the world consists of good and evil only. It is not concerned about the fact that there is a great distance between what people do and what they intend, what people say and what they mean, and what is imagined and what is real. Manichean dualistic worldview is like a weapon necessary for an urgent battle, rather than a helpful instrument to understand the world in a careful manner. Its dualism, combined with Common-Sense Realism, lets its adherents clearly separate friends from foes and easily discern good and evil. As such, Manichean dualism is a highly effective tool for Protestant anti-communists to enlist friendly forces and expand the war front in an ideologically hypersensitive Korean social setting where words like "communism" or "leftist" can instantly arouse animosity in many people. This explains why Korean conservative Protestants, who waged a war against the "proNorth Korea leftists," were in a desperate sense of crisis, why they were so infuriated with their enemies, and why they were so resolute in battle.

However, such a theological and worldview-related reason cannot fully explain the political activism of Protestant conservatives. Just like the evangelical-fundamentalist churches of the United States, Korea's conservative Protestants have obeyed political authorities and have optimized themselves for the capitalistic market economy. Hence, their political actions should be closely linked to political and economic factors. This is where the "power vacuum" comes in. Korea during the Kim Dae-Jung and Roh MooHyun administrations was in a strange situation in which both the progressives and conservatives felt they were under attack and were in danger. The progressives failed to come out of the victim mentality they had felt since the period of military dictatorship even after they took power, while the conservatives felt their long-held capitalist values and Cold War structures being shaken and their vested rights being attacked as progressive governments took office. This kind of mutual victim mentality probably arose from a "power vacuum" during the transitional period where neither camp held actual dominance. The anger and the sense of crisis felt by Protestant conservatives also came 
from the victim mentality. Considering conservative Protestants were traditionally obedient to those in powers, their political activities in the early 2000s were probably attributable to the "power vacuum."

With the inauguration of the Lee Myung-Bak administration, Korea returned to the old anti-communist tradition. For the first few years of the Lee administration, there were many worried voices about the "pro-North Korea leftists" who still remained in the Republic of Korea. Yet the Lee administration was succeeded by the Park GeunHye administration, a much more ideologically conservative regime. The launching of conservative policies by the Park administration, which were strongly reminiscent of anti-communist policies before the progressive administrations, means that the aforementioned power vacuum has been filled at least in terms of politics. Under an anticommunist government, Protestant conservatives would rarely feel a sense of urgency as they did under the Kim and Roh administrations, and hence would not take action as they did at that time. After all, what they are trying to achieve will be done by the Park government. They only need to do their part by occasionally attacking the suspects that the government had better not deal with. Their campaign against the WCC General Assembly held in Busan, Korea in 2013 was one such incident. Conservative Protestants insisted that the WCC was a pro-communist organ and should not be allowed to hold a meeting in Korea.

In the future, as before, Protestant conservatives' anti-communist sentiment will be sustained by the division on the Korean Peninsula. In North Korea, Kim Jong-Un inherited the regime from his father Kim Jong-Il. While one does not know what kind of changes the younger Kim will pursue in the future, what is certain is that he will never give up the socialism that the North Korean rulers have adhered to since his grandfather Kim Il-Sung. With the coming of the Park administration, ideological tensions between the South and the North have been considerably heightened. The Cold-War structure in South Korea, resulting from the national division and weakened during the Kim and Roh administrations, has become solidified again. Unless this structure is at risk, that is, unless South Korea's capitalist and anti-communist system and values are shaken and another "power vacuum" is created, Protestant conservatives would find it difficult to find the courage or momentum to turn themselves toward political activism again.

\section{Endnotes}

${ }^{1}$ All East Asian personal names in the article have their family name first, except those in English-language journals that usually write their family name last.

${ }^{2}$ "We Will Protect Korea: A March First National Meeting to Eradicate the Leftists Held in front of the City Hall," News and Joy, March 4, 2004 [in Korean].

${ }^{3}$ The word "counterattack" was first used in "The 'Counterattack' by Regrouped Korean Conservatives," Shindonga (Oct. 2003): 296-307 [in Korean].

4 "The New Right: From Silence to Activism," Dong-A Ilbo, Nov. 7, 2004 [in Korean].

${ }^{5}$ Lee Han-Woo, "Human Network of the Korean New Right," Monthly Chosun (Sep. 2005): 288-301 [in Korean].

${ }^{6}$ Lloyd Billingsley, "Radical Evangelicals and the Politics of Compassion," in Piety and Politics: Evangelicals and Fundamentalists Confront the World, eds. Richard J. Neuhaus and Michael Cromartie (Washington, D.C.: Ethics and Public Policy Center, 1987), 214-15. 
${ }^{7}$ It is not altogether clear what the political conservatives intend to "conserve." See "The Present and Future of Korean Political Powers," Dong-A Ilbo (March 8, 2004) [in Korean].

${ }^{8}$ Joel A. Carpenter, Revive Us Again: The Reawakening of American Fundamentalism (New York: Oxford University Press, 1997), 16, 63, 118; George M. Marsden, Fundamentalism and American Culture: The Shaping of Twentieth-Century Evangelicalism, 1870-1925 (New York: Oxford University Press, 1982), 208-211.

${ }^{9}$ Richard H. Mitchell, Janus-Faced Justice: Political Criminals in Imperial Japan (Honolulu: University of Hawaii Press, 1992), 57, 68-70, 81, passim.

${ }^{10}$ Robert A. Scalapino and Chong-Sik Lee, Communism in Korea, Part I: The Movement (Berkeley: University of California Press, 1972), 189-201.

${ }^{11}$ Dae Young Ryu, "Missionaries and Imperial Cult: Politics of the Shinto Shrine Controversy in Colonial Korea," Diplomatic History, vol. 40, no. 4 (2016): 606, 618-19.

${ }^{12}$ See, for instance, Mattie Wilcox Noble, Diary of May 5, 1925 in The Journal of Mattie Wilcox Noble, 1892-1934 (Seoul: Institute for History of Christianity in Korea, 2003), 360; James E. Fisher, Democracy and Mission Education in Korea (Seoul: Yonsei University Press, 1970 [originally published in 1928]), 164-66; Edwin W. Koons, "Present Day Social Problems," Korea Mission Field 31 (Jan. 1935): 11.

${ }^{13}$ Sawa Masahiko, On History of Christianity in South and North Korea, trans. Kim Sook-Ja and Kang Min-Gyu (Seoul: Minjungsa, 1997), 165, 324-25 [in Korean].

${ }^{14}$ See, for instance, various anti-communist sermons in Han Kyung-Jik, Nation-Building and Christianity (Seoul, Borinwon, 1949) [in Korean].

${ }^{15}$ Yoon Jeong-Ran, The Korean War and Protestantism (Seoul: Hanul Academy, 2015), 110-113, 149-55 [in Korean]; Kang In-Chul, Korean Protestantism and AntiCommunism (Seoul, Jungsim, 2007), 514-30 [in Korean].

${ }^{16}$ Lew Young Ick, Rhee Syngman, the President who Found the Country (Seoul: Iljogak, 2013), 211-14 [in Korean]; Kang In-Chul, The Korean Church and NationCivic Society, 1945-1960 (Seoul: Institute for History of Christianity in Korea, 2003), 162-89 [in Korean].

${ }^{17}$ Quoted in Lew, 180.

${ }^{18}$ Kang, Korean Protestantism, 65-69; Kim Heung-Soo, A Study of the Korean War and the Spread of Faith for Blessing (Seoul, Institute for History of Christianity in Korea, 1999), 57-77 [in Korean].

${ }^{19}$ Kim Jae-Jun, Writings of Jang Gong Kim Jae-Jun II (Seoul, Korea Theological University Press, 1971), 302 [in Korean].

${ }^{20}$ Yun, 74-88; Kim Heung-Soo, "Relief Activities of Foreign Christian Voluntary Agencies during the Korean War," Christianity and History in Korea 23 (Sep. 2005): 97-121 [in Korean].

${ }^{21}$ Dae Young Ryu, "Korean Protestant Churches' Attitude toward War: With a Special Focus on the Vietnam War," Korea Journal 44 (Winter 2004): 191-222.

${ }^{22}$ Ryu Dae Young and Kim Heung-Soo, A New Understanding of Religion in North Korea (Seoul, Dasangeulbang, 2002), 247-48 [in Korean].

${ }^{23}$ Hong Eun Kwang, "A Study on the Adaptation and Influence of Freirean Pedagogy in the Korean Popular Education" (M.Ed. Thesis, Seoul National University, Seoul, Korea, 2003), 134.

${ }^{24}$ George F. Will, "Who Put Morality in Politics?," in Piety and Politics, 261. 
${ }^{25}$ Harvey Cox, Religion in the Secular City: Toward A Postmodern Theology (New York: Simon and Schuster, 1984), 62.

${ }^{26}$ Martin E. Marty, "Fundamentalism as a Social Phenomenon," in Piety and Politics, 308, 310 .

${ }^{27}$ Ryu Dae Young, “The Theological Background of Conservative Churches' Social Activism since the 1980s," Christianity and History in Korea 18 (Feb. 2003): 71-72 [in Korean].

${ }^{28}$ On the "Cold-War structure," see Choe Jang-Jib, Democracy after Democratization: The Origin and Crisis of Korean Democracy (Seoul: Humanitas, 2002), esp. 41-66, 213-14 [in Korean].

29 "Declaration of Inauguration," www.christianngo.org [in Korean], last accessed on March 30, 2004.

30 "Founding Declaration of the New Right Network," www.hankiun.net [in Korean], last accessed on 30 Mar 2004.

31 "Statement of the Intent of Initiation," www.newright.net [in Korean], last accessed on 30 Mar 2004.

32 "Founding Declaration of The Christian New Right Alliance," www.newright.net [in Korean], last accessed on 30 Mar 2004.

33 "Statement of the Intent of Initiation."

34 "Founding Declaration of the Civil Action for Advancement," www.sunjingo.org [in Korean], last accessed on 30 Mar 2004; "Founding Declaration of the New Right Network."

${ }^{35}$ See, for instance, Min Byung-Ho and Na Gi-Whan, The New Right Shall Change the World (Seoul: Yeareum Media, 2007), 223-29 [in Korean]; Shin Ji-Ho, The Way the New Right Sees the World (Seoul: Giparang, 2006), 40-78 [in Korean]; "Historical Perspective of the New Right," www.newright.net [in Korean], last accessed on March 30, 2004.

36 "Historical Perspective of the New Right."

${ }^{37}$ Jung Hyo-Im, "The Christian Party Began Wriggling Again to Save the Country from the Leftists," News and Joy, Nov. 11, 2008 [in Korean].

38 "Founding Declaration," www.sunjingo.org [in Korean], last accessed on March 30, 2004.

${ }^{39}$ Seo Gyung-Seok, "Why Am I a Turncoat? Dongbuka Shinmun, June 16, 2008, www.dbanews.com/news/articleView.html?idxno=8006 [in Korean], last accessed on March 13, 2017.

40 "What is the Communal Liberalism," www.newright.net [in Korean], last accessed on 30 Mar 2004; Min and Na, 177-82; Shin, 200-202.

${ }^{41}$ Richard Hofstater's study quoted in George M. Marsden, Fundamentalism and American Culture: The Shaping of Twentieth-Century Evangelicalism, 1870-1925 (New York: Oxford University Press, 1982), 210-11.

42 Pheme Perkins, "Mani, Manichaeism," in Encyclopedia of Early Christianity, ed. Everett Ferguson (New York: Garland, 1990), 362-63.

${ }^{43}$ Marty, 309.

${ }^{44}$ George M. Marsden, Understanding Fundamentalism and Evangelicalism (Grand Rapids: Eerdmans, 1991), 117-18.

${ }^{45}$ Ibid., 192-94.

${ }^{46}$ Marsden, Fundamentalism and American Culture, 211. 
${ }^{47}$ Grand Wacker, "Searching for Norman Rockwell: Popular Evangelicalism in Contemporary America," in The Evangelical Tradition in America, ed. Leonard I. Sweet (Atlanta: Mercer University Press, 1984), 303.

${ }^{48}$ Francis A. Schaeffer, How Should We Then Live?: The Rise and Decline of Western Thought and Culture (New York: Fleming H. Revell, 1979), 32.

${ }^{49}$ Francis Schaeffer, A Christian Manifesto (Westchester, IL: Crossway, 1981), 23.

${ }^{50}$ Ryu Dae Young, Early American Missionaries in Korea (1884-1910): Understanding Missionaries from Their Middle-Class Background (Seoul: Institute for History of Christianity in Korea, 2013), 91-98, 105-34 [in Korean].

${ }^{51}$ Dae Young Ryu, "Missionaries and Imperial Cult"; Ryu Dae-Young, "American Presbyterian Missionary Edwin W. Koons: The Shinto Shrine Controversy and Participation in Anti-Japanese Psychological Warfare," Dong Bang Hak Chi 170 (June 2015): 113-42 [in Korean]; Ryu Dae Young, “The 'Minority' Opinion of the Shinto Shrine Controversy: The Case of Harold H. Henderson," Christianity and History in Korea 39 (Sep. 2013): 145-78 [in Korean].

52 "Inauguration of the ' $3 \cdot 1$ Crusade' to Eradicate Communism," News and Joy, March 4, 2004 [in Korean].

${ }^{53}$ Ibid.

${ }^{54}$ James Davison Hunter, American Evangelicalism: Conservative Religion and the Quandary of Modernity (New Brunswick: Rutgers University Press, 1981), 43-44.

${ }^{55}$ Kang, Korean Protestantism, 68-72.

Acknowledgements

This article is based on the author's two previously published essays in Korean: "The Ideology and World-view of the Korean Christian Right," The Critical Review of Religion and Culture 15 (March 2009): 43-71; "Understanding Conservative Christians' Pro-American and Anti-Communist Activities in the Early Twenty-First Century," Economy and Society 62 (Summer, 2004): 54-79.

Funding

None.

Competing interests

The author declares that he has no competing interests.

Received: 11 November 2016 Accepted: 31 January 2017

Published online: 27 March 2017

\section{Submit your manuscript to a SpringerOpen ${ }^{\mathcal{O}}$ journal and benefit from:}

- Convenient online submission

- Rigorous peer review

- Immediate publication on acceptance

- Open access: articles freely available online

- High visibility within the field

- Retaining the copyright to your article

Submit your next manuscript at $>$ springeropen.com 